\title{
PENGARUH GOOD CORPORATE GOVERNANCE TERHADAP KINERJA BANK SYARIAH MANDIRI DI INDONESIA PERIODE 2013-2016.
}

\begin{abstract}
Abstrak
Perkembangan Bank Syariah di Indonesia sangatlah pesat. Terbukti pada salah satu Bank Syariah di Indonesia yaitu Bank Syariah Mandiri yang dilihat dari aset perbankannya. Tujuan dari penelitian ini adalah mengetahui adanya pengaruh GCG terhadap Kinerja Bank Syariah Mandiri di Indonesia periode 2013-2016. Metode penelitian ini menggunakan data sekunder yang diperoleh dari laporan keuangan bank dan laporan good corporate governance yang dipublikasikan oleh Otoritas Jasa Keuangan atau website Bank Syariah Mandiri periode 2013-2016. Selain itu penelitian ini merupakan penelitian kuantitatif dengan menggunakan data time series and cross section dari tahun 2013-2016. Hasil penelitian menunjukkan bahwa Ukuran dewan komisaris berpengaruh positif dan signifikan terhadap kinerja keuangan Bank Syariah Mandiri periode 2013-2016, sehingga $\mathrm{H}_{1}$ diterima. Ukuran dewan direksi tidak berpengaruh signifikan terhadap kinerja keuangan Bank Syariah Mandiri periode 2013-2016, sehingga $\mathrm{H}_{2}$ ditolak. Ukuran dewan pengawas syariah tidak berpengaruh signifikan terhadap kinerja keuangan Bank Syariah Mandiri periode 2013-2016, sehingga $\mathrm{H}_{3}$ ditolak.

Kata Kunci Ukuran Dewan Komisaris, Ukuran Dewan Direksi, Ukuran Dewan Pengawas Syariah, GCG, ROA.
\end{abstract}

\section{PENDAHULUAN}

Perkembangan Bank Syariah di Indonesia sangatlah pesat. Terbukti pada salah satu Bank Syariah di Indonesia yaitu Bank Syariah Mandiri yang dilihat dari aset perbankannya, berdasarkan annual report BSM tahun 2016 menyatakan adanya pertumbuhan sebesar $12,02 \%$. Hal ini dapat memberikan dampak yang baik terhadap kinerja perbankan syariah. Kinerja perbankan sangat erat hubungannya dengan peran dan fungsi manajemen dari bank tersebut. Bank dinyatakan berhasil apabila menghasilkan suatu keuntungan dan hal tersebut merupakan suatu prestasi yang dilakukan oleh pihak manajemen. Corporate Governance yang merupakan konsep untuk peningkatan kinerja perusahaan melalui supervisi atau monitoring kinerja manajemen serta menjamin akuntabilitas manajemen terhadap stakeholder dengan mendasarkan pada kerangka peraturan (M. Nasution dan D. Setiawan, 2007).

Bank Syariah Mandiri telah memulai komitmennya untuk menerapkan GCG merujuk kepada pemegang saham yakni PT. Bank Mandiri Tbk. dan panduan dari buku pedoman GCG yang diterbitkan Forum for Corporate Governance in Indonesia (FCGI). Secara bertahap, sesuai dengan perkembangan industri, maka Bank Syariah Mandiri mengadopsi pula panduan dari Komite Nasional (Komnas) Corporate Governance yang menerbitkan Pedoman Corporate Governance Perbankan Indonesia (Indonesian Banking Sector Code) pada Maret 2004. BSM dalam mengoptimalkan 
penerapan GCG melakukan penguatan infrastruktur, restrukturisasi internal yang mengarah kepada praktik terbaik, penyesuaian dan pembaharuan sistem dan prosedur yang diperlukan untuk mendukung pelaksanaanya.

Konsep corporate governance diajukan demi tercapainya pengelolaan perusahaan yang lebih transparan bagi para stakeholders. Sistem corporate governance memberikan perlindungan efektif bagi stockholder dan stakeholder sehingga mereka akan yakin memperoleh imbal hasil atas investasinya dengan benar. Corporate governance juga membantu menciptakan iklim kondusif demi terciptanya pertumbuhan yang efisien dan berkesinambungan di sektor korporasi. Pelaksanaan GCG sangat diperlukan untuk membangun kepercayaan masyarakat dan dunia Internasional sebagai syarat bagi dunia perbankan untuk berkembang dengan baik.

Penerapan good corporate governance dalam suatu perusahaan dapat dilihat melalui pelaporan keuangan yang mencerminkan kinerja perusahaan tersebut. Kinerja keuangan bank merupakan gambaran kondisi keuangan bank pada suatu periode tertentu baik menyangkut aspek penghimpunan dana maupun penyaluran dana sehingga dapat menarik perhatian investor. Salah satu alat pengukuran kinerja keuangan adalah dengan menggunakan indikator profitabilitas. Profitabillitas merupakan kemampuan suatu perusahaan untuk mendapatkan laba (keuntungan) dalam suatu periode tertentu (Simanjuntak, 2011). Terdapat kelemahan dalam menerapkan GCG yang ditandai dengan perilaku manajemen dimulai mementingkan kepentingan pribadi dan sampai merugikan perusahaan.

Penelitian terdahulu telah menguji mengenai dampak corporate governance terhadap kinerja bank dilakukan oleh Bukhori (2012) yang mengukur dengan cash flow return on asset, hasil penelitian menunjukan bahwa ketiga variabel yaitu dewan direksi, dewan komisaris, serta ukuran perusahaan tidak berpengaruh signifikan terhadap kinerja perusahaan. Danang (2013) melakukan penelitian mengenai analisis penerapan GCG terhadap kinerja keuangan perusahaan dengan indikator dewan komisaris, dewan direksi, kepemilikan institusional dan kepemilikan manajerial yang menghasilkan semua variabel berpengaruh signifikan terhadap kinerja perusahaan diukur dengan Tobin'q. Selain itu Widagdo (2014) melakukan penelitian yang serupa untuk menguji pengaruh GCG terhadap kinerja perusahaan dengan variabel independensi komite audit, dewan komisaris, kepemilikan manajerial, jumlah rapat dewan komisaris, dan jumlah rapat komite audit tidak berpengaruh terhadap kinerja keuangan, dan hanya dewan komisaris yang berpengaruh positif.

\section{LANDASAN TEORI \\ 1. Bank Syariah}

Menurut pasal 1 angka 7 uu no. 21 tahun 2008, bank syariah adalah bank yang menjalankan kegiatan usahnya berdasarkan prinsip syariah. terkait dengan asas operasional bank syariah, berdasarkan pasal 2 undang-undang no. 21 tahun 2008, disebutkan bahwa perbankan syariah dalam melakukan kegiatan usahanya berdasarkan prinsip syariah, selanjutnya, terkait dengan tujuan bank syariah, yaitu pada pasal 3 dinyatakan bahwa perbankan syariah bertujuan menunjang pelaksanaan pembangunan nasional dalam rangka meningkatkan keadilan, kebersamaan, dan pemerataan kesejahteraan rakyat. kemudian pasal 4 undang-undang no. 21 tahun 2008 tentang perbankan syariah, disebutkan bahwa bank syariah wajib menjalankan 
fungsi menghimpun dan menyalurkan dana masyarakat (yaya, martawireja, dan abdurahim, 2009:54). bank syariah merupakan bank yang secara operasional berbeda dengan bank konvensional. salah satu cirri khas bank syariah yaitu tidak menerima atau membebani bunga kepada nasabah, tetapi menerima atau membebankan bagi hasil serta imbalan lainh sesuai dengan akad-akad yang diperjanjikan. konsep dasar bank syariah didasarkan pada al-quran dan hadis. semua produk jasa yang ditawarkan tidak boleh bertentangan dengan isi al-quran dan hadis rasulullah saw. menurut (ismail, 2011:39), bank syariah memiliki tiga fungsi utama yaitu menghimpun dana dari masyarakat dalam bentuk titipan dan investasi, menyalurkan dana kepada masyarakat yang membutuhkan dana dari bank, dan juga memberikan pelayanan dalam bentuk jasa perbankan syariah.

\section{Good Corporate Governance}

Menurut forum for corporate governance in Indonesia (FCGI), mendefinisikan sebagai seperangkat peraturan yang mengatur hubungan antara pemegang, pengurus perusahaan, pihak kreditur, pemerintah, karyawan, serta para pemegang kepentingan internal dan eksternal lainnya yang berkaitan dengan hak dan kewajiban atau mengendalikan perusahaan dengan tujuan untuk menciptakan nilai tambah bagi semua pihak yang berkepentingan. Selain itu, corporate governance menurut organization for economic corperation and development (OECD) adalah struktur yang mengatur para pemegang saham, komisaris, manajer dalam menyusun tujuantujuan serta mengawasi kinerja. Corporate governance merupakan seperangkat tata hubungan diantara manajemen perseroan, direksi, komisaris, pemegang saham dan para pemangku kepentingan lainnya.

Good Corporate Governance terdiri dari dua unsur, yaitu unsur yang berasal dari dalam perusahaan dan unsur yang berasal dari luar perusahaan. Corporate governance internal perusahaan adalah unsur yang selalu diperlukan dalah perusahaan dan sangat berperan dalam mengelola perusahaan, jika internal perusahaan baik maka kinerja pun akan mengikuti. Sedangkan corporate governance eksternal perusahaan adalah unsur yang selalu dibutuhkan atau diperlukan diluar perusahaan dan mempunyai pengaruh terhadap kinerja keuangan perusahaan.

Berdasarkan pengertian mengenai corporate governance tersebut, maka dapat disimpulkan bahwa Good Corporate Governance adalah suatu sistem pengelolaan perusahaan yang dirancang untuk meningkatkan kinerja perusahaan, melindungi kepentingan stakeholders dan meningkatkan kepatuhan terhadap peraturan perundang-undangan serta nilai-nilai etika yang berlaku secara umum.

Seiiring dengan perkembangan dalam industri perbankan syariah, penerapan Good Corporate Governance menjadi sebuah keharusan dan tampil sebagai pionir terdepan dalam mengimplementasikannya. Oleh karena itu, IFSB (Islamic Financial Service Board) adalah sebuah badan penetapan standar Internasional untuk regulasi lembaga keuangan Islam yang berpusat di kuala lumpur sebagai pedoman pelaksanaan tata kelola perusahaan lembaga keuangan syariah di semua negara atau yang lebih dikenal dengan istilah Sharia Governance. Konsep GCG yang dikeluarkan oleh IFSB atau sering disebut Sharia Governance sebagian besar memiliki prinsip yang sama dengan GCG konvensional pada umumnya, hanya saja perbedaan terletak pada syariah compliance yaitu kepatuhan pada syariah. 


\section{Kinerja Keuangan}

Kinerja keuangan sering dijadikan dasar untuk melakukan penilaian terhadap kinerja perusahaan. Kinerja keuangan dapat diartikan sebagai kondisi perusahaan sehingga diperlukan ukuran-ukuran tertentu untuk menganalisis kinerja keuangan suatu perusahaan. Kinerja perusahaan dapat dinilai melalui dua aspek yaitu aspek keuangan dan aspek non keuangan. Penilaian aspek keuangan dapat dilakukan dengan menganalisis laporan keuangan yang disusun oleh manajemen. Dengan menganalisis pos-pos yang terdapat di dalam laporan keangan, kemudian dapat ditemukan rasiorasio yang digunakan sebagai indikator baik atau tidaknya kinerja keuangan perusahaan.

Keberhasilan dalam mencapai tujuan perusahaan merupakan prestasi manajemen. Penilaian prestasi atau kinerja suatu perusahaan diukur karena dapat dipakai sebagai dasar pengambilan keputusan baik pihak internal maupun eksternal. Penilaian kinerja keuangan merupakan salah satu cara yang dapat dilakukan oleh pihak manajemen agar dapat memenuhi kewajibanya terhadap penyandang dana dan juga untuk mencapai tujuan yang telah ditetapkan oleh perusahaan. Kinerja merupakan indikator dari baik buruknya keputusan manajemen dalam pengambilan keputusan. Manajemen dapat berinteraksi dengan lingkungan internal maupun eksternal melalui informasi. Informasi tersebut lebih lanjut diungkapkan dalam laporan keuangan perusahaan. Manfaat penilaian kinerja keuangan yaitu:

1.Digunakan untuk mengukur prestasi yang dicapai oleh suatu organisasi dalam periode tertentu yang mencerminkan keberhasilan pelaksanaan kegiatanya.

2. Selain digunakan untuk melihat kinerja organisasi secara keseluruhan, maka pengukuran kinerja juga dapat digunakan untuk menilai konstribusi suatu bagian dalam pencapaian tujuan perusahaan secara keseluruhan.

3. Dapat digunakan sebagai dasar penetuan strategi perusahaan untuk masa depan.

4. Memberi petunjuk dalam pembuatan keputusan dan kegiatan organisasi pada umumnya dan divisi atau bagian organisasi pada khususnya.

5. Sebagai dasar penentuan kebijakan penanaman modal agar dapat meningkatkan efisien dan produktivitas perusahaan.

Kinerja keuangan merupakan salah satu faktor yang menunjukan efektifitas dan efisien suatu organisasi dalam rangka mencapai tujuanya. Efektifitas apabila manajemen memiliki kemampuan untuk memilih tujuan yang tepat untuk mencapai tujuan yang telah ditetapkan. Efisiensi diartikan sebagai rasio (perbandingan) antara masukan dan keluaran yaitu dengan masukan tertentu memperoleh keluaran yang optimal. Dengan begitu pengertian kinerja adalah suatu usaha formal yang dilaksanakan perusahaan untuk mengevaluasi efisien dan efektivitas dari aktifitas perusahaan yang telah dilaksanakan pada periode tertentu (Hanafi, 2000).

Kondisi kinerja keuangan perusahaan dapat tercermin pada laporan keuangan melalui analisis rasio-rasio keuangan. Analisis rasio keuangan adalah cara menganalisis dengan menggunakan perhitungan-perhitungan perbandingan atas kuantitatif yang ditunjukkan dalam laporan keuangan. Laporan keuangan adalah hasil akhir dari proses akuntansi yang disusun dengan tujuan untuk memberikan informasi keuangan suatu perusahaan. Informasi keuangan tersebut dapat digunakan oleh para pemakai untuk pengambilan keputusan investasi. Return on assets (ROA) merupakan 
salah satu rasio yang digunakan untuk mengukur tingkat profitabilitas perusahaan. Return on asset digunakan untuk mengukur besarnya laba bersih yang dapat diperoleh dari operasional perusahaan dengan menggunakan seluruh kekayaannya. Tinggi rendahnya ROA tergantung pada pengelolaan asset perusahaan yang menggunakan efisiensi operasional perusahaan.

\section{Ukuran Dewan Komisaris}

Berdasarkan Undang-undang No.21 tahun 2008 tentang perbankan syariah dan peraturan Bank Indonesia No.11/33/PBI/2009 tentang pelaksanaan GCG bagi bank syariah, Dewan Komisaris senantiasa melaksanakan tugas dan tanggung jawabnya secara profesional dan independen dengan pedoman pada tata kelola perusahaan yang baik. Dewan komisaris sebagai puncak dari sistem pengelolaan internal perusahaan, memiliki peranan terhadap aktivitas pengawasan. Dalam rangka menjalankan tugasnya, dewan komisaris mengadakan rapat-rapat untuk mengevaluasi kebijakan-kebijakan yang diambil oleh dewan direksi. Berdasarkan peraturan Bank Indonesia No.11/33/PBI/2009 pasal 14, rapat dewan komisaris wajib diselenggarakan paling kurang satu kali dalam dua bulan dan dihadiri paling kurang dua pertiga dari jumlah anggota dewan komisaris. Rapat Dewan Komisaris merupakan media komunikasi dan koordinasi antar anggota dewan dan membahas masalah mengenai arah dan strategi perusahaan, evaluasi kebijakan yang telah diambil atau dilakukan oleh manajemen,serta mewajibkan telaksananya akuntabilitas. sehingga semakin sering mengadakan rapat diharapkan semakin baik dalam melakukan pengawasan.

\section{Ukuran Dewan Direksi}

Menurut Nation Committe For Corporate Governance (NCGG), kriteria kerangka kerja GCG salah satunya adalah dewan direksi yang dalam pemenuhan fungsinya ditugaskan dengan seluruh manajemen perusahaan. Prosedur dewan direksi menggunakan professional independen atau komite khusus yang ada. Komposisi dewan direksi harus mempertimbangkan efektivitas dan kecepatan dalam mengambil keputusan. Agar tercipta corporate governance yang efektif pada perbankan syariah maka, anggota dewan direksi harus memiliki reputasi moral yang baik dan kompetensi teknis yang mendukung. Selain itu juga mereka harus memiliki kesadaran yang penuh terhadap segala risiko, memiliki kemampuan untuk mengelola risiko seiring dengan kompleksitas bisnis perbankan.

\section{Ukuran Dewan Pengawas Syariah}

Dewan pengawas syariah (DPS) adalah istilah umum yang digunakan di Indonesia untuk menyebut institusi pengawasan internal syariah di bank syariah. Beberapa negara menyebut DPS sebagai Sharia Supersony Board, or Sharia Committee and Sharia council. Penerapan Good Corporate Governance pada bank syariah menjadi sangat penting. Hal ini dikarenakan bank syaria memiliki perbedaan dengan bank konvensional, salah satunya yaitu penerapan Sharia compliance. Dewan pengawas syariah adalah lembaga independen atau hakim khusus dalam fiqh muamalat namun DPS juga bisa anggota diluar ahli fiqh dalam bidang lembaga keuangan islam dan fiqh muamalat. Tugas dan tanggung jawab Dewan Pengawas Syariah mengacu pada peraturan Bank Indonesia No.11/33/PBI/2009 tentang 
pelaksanaan GCG bagi bank syariah. Pelaksanaan tugas dan tanggung jawab DPS diwujudkan dalam bentuk pengawasan terhadap pemenuhan prinsip syariah.

\section{METODOLOGI PENELITIAN}

Penelitian ini merupakan penelitian kausal karena tujuan penelitian ini adalah meneliti hubungan sebab akibat antara dua variabel yaitu variabel independen terhadap variabel dependen. Konsep indikator mekanisme corporate governance atau dalam hal ini merupakan variabel independen, peneliti membatas pada indikator ukuran dewan komisaris, ukuran dewan direksi, ukuran dewan pengawas syariah. Selanjutnya variabel yang kedua merupakan variabel dependen yang dalam penelitian ini adalah kinerja keuangan. Untuk mengukur kinerja keuangan dalam penelitian ini digunakan Return on Asset (ROA).

Penelitian ini menggunakan data sekunder yang diperoleh dari laporan keuangan bank dan laporan good corporate governance yang dipublikasikan oleh Otoritas Jasa Keuangan atau website Bank Syariah Mandiri periode 2013-2016. Selain itu penelitian ini merupakan penelitian kuantitatif dengan menggunakan data time series and cross section dari tahun 2013-2016.

Populasi dalam penelitian ini adalah seluruh Bank Syariah Mandiri di Indonesia, selama periode 2013-2016. Peneliti memperoleh data-data penelitian yang bersumber dari:

\section{Penelitian Pustaka (Library research)}

Peneliti memperoleh data yang berkaitan dengan masalah yang sedang diteliti melalui buku, artikel, jurnal, laporan penelitian, tesis dan perangkat lain yang berkaitan dengan penelitian ini.

\section{Penelitian Lapangan (Field research)}

Data sekunder yang digunakan dalam penelitian ini dikumpulkan dari laporan keuangan dan laporan Good corporate governance dari Bank Syariah Mandiri selama periode 2013-2016.

Untuk menguji hipotesis penelitian dari variabel-variabel diatas, maka digunakan teknik multiple regesi dengan rumus sebagai berikut (Sugiyono, 2007).

$$
\begin{aligned}
& Y=\alpha+\beta_{1} X_{1}+\beta_{2} X_{2}+\beta_{3} X_{3}+\varepsilon \\
& \text { Dimana: } \\
& \mathrm{Y} \quad=\text { Kinerja Keuangan } \\
& \mathrm{X}_{1}=\text { Ukuran Dewan Komisaris } \\
& \mathrm{X}_{2} \quad=\text { Ukuran Dewan Direksi } \\
& \mathrm{X}_{3}=\text { Ukuran Dewan Pengawas Syariah } \\
& \alpha \quad=\text { Konstanta } \\
& \beta \quad=\text { Koefisien Regresi } \\
& \varepsilon \quad=\text { Error }
\end{aligned}
$$




\section{HASIL PENELITIAN}

Analisis regresi berganda bertujuan mengetahui pengaruh good corporate governance terhadap kinerja keuangan perbankan syariah di Indonesia. Adapun berdasarkan perhitungan diperoleh hasil sebagai berikut:

Tabel 1

Hasil Pengujian Regresi Linier Berganda

Sesudah Memasukkan Variabel Kontrol

\begin{tabular}{|l|l|l|l|l|}
\hline \multicolumn{1}{|c|}{ Variabel } & Coefficient & Beta & thitung & $P$ \\
\hline (Constant) & 0,013 & & 0,289 & 0,775 \\
Dewan Komisaris & 0,005 & 0,343 & 2,656 & 0,039 \\
Dewan Direksi & $-0,002$ & $-0,131$ & $-0,948$ & 0,540 \\
Dew. Pengawas Syari'ah & 0,007 & 0,215 & 1,160 & 0,520 \\
Ukuran Bank & $-0,001$ & $-0,137$ & $-0,717$ & 0,481 \\
\hline $\mathrm{R}^{2}=0,680$ & & \\
Fhitung $=5,090$ & & \\
$\mathrm{p} \quad=0,002$ & \\
\hline
\end{tabular}

Sumber: data diolah

\section{Pengaruh Ukuran Dewan Komisaris terhadap Kinerja Keuangan}

Hasil penelitian tentang pengaruh ukuran dewan komisaris terhadap kinerja keuangan perusahaan perbankan di Indonesia dengan ukuran bank sebagai variabel kontrol diperoleh nilai thitung sebesar 2,656 dengan $\mathrm{p}=0,039$. Hasil perhitungan menunjukkan bahwa nilai $\mathrm{p}<0,05$; maka $\mathrm{H}_{1}$ diterima, yang berarti bahwa ukuran dewan komisaris berpengaruh signifikan terhadap kinerja keuangan perusahaan perbankan di Indonesia dengan ukuran bank sebagai variabel kontrol.

Dewan komisaris adalah sebuah dewan yang bertugas untuk melakukan pengawasan dan memberikan nasihat kepada direktur perusahaan (id.wikipedia.org). Salah satu tugas dan tanggung jawab dewan komisaris dalam PBI No. 11/33/PBI/2009 adalah melakukan pengawasan terhadap kegiatan Bank Umum Syariah. Menurut Chtourou, dkk (2001) dalam Dewayanto (2010) menyatakan bahwa jumlah dewan yang semakin besar maka mekanisme monitoring manajemen perusahaan akan semakin baik. Selain itu, menurut Bukhori dan Raharja (2012), dengan semakin banyak anggota dewan komisaris, pengawasan terhadap dewan direksi jauh lebih baik, masukan atau opsi yang akan didapat direksi akan jauh lebih banyak. Dapat disimpulkan bahwa semakin besar jumlah dewan komisaris maka pengawasan akan semakin efektif. Dengan demikian, penyalahgunaan yang dapat menurunkan kinerja keuangan bank dapat diminimalisir dengan lebih baik sehingga kinerja keuangan bank dapat meningkat.

\section{Pengaruh Ukuran Dewan Direksi terhadap Kinerja Keuangan}

Hasil penelitian tentang pengaruh ukuran dewan direksi terhadap kinerja keuangan perusahaan perbankan di Indonesia dengan ukuran bank sebagai variabel kontrol diperoleh nilai thitung sebesar $-0,948$ dengan $\mathrm{p}=0,540$. Hasil perhitungan 
menunjukkan bahwa nilai $\mathrm{p}>0,05$; maka $\mathrm{H}_{2}$ ditolak, yang berarti bahwa ukuran dewan direksi tidak berpengaruh signifikan terhadap kinerja keuangan perusahaan perbankan di Indonesia dengan ukuran bank sebagai variabel kontrol.

Dewan direksi dalam sebuah perusahaan merupakan seseorang yang memiliki perusahaan tersebut atau orang profesional yang ditunjuk oleh pemilik usaha untuk menjalankan dan memimpin perusahaan (id.wikipedia.org). Salah satu tugas dan tanggung jawab dewan direksi dalam PBI No. 11/33/PBI/2009 adalah mengelola Bank Umum Syariah agar berjalan sesuai dengan prinsip syariah. Alexander, Fernell, Halporn (1993) dan Goodstein, Gautarn, Boeker (1994) dalam Wardhani (2006) menyatakan bahwa jumlah dewan yang besar menguntungkan perusahaan dari sudut pandang resource dependence yaitu bahwa perusahaan tergantung dengan dewannya untuk dapat mengelola sumber daya secara lebih baik. Dengan demikian, semakin besar jumlah dewan direksi maka pengelolaan sumber daya pada Bank Syariah akan semakin baik. pengelolaan atau manajemen perusahaan yang baik secara tidak langsung akan meningkatkan kinerja keuangan.

\section{Pengaruh Ukuran Dewan Pengawas Syariah terhadap Kinerja Keuangan}

Hasil penelitian tentang pengaruh ukuran dewan pengawas syariah terhadap kinerja keuangan perusahaan perbankan di Indonesia dengan ukuran bank sebagai variabel kontrol diperoleh nilai thitung sebesar 1,160 dengan $\mathrm{p}=0,520$. Hasil perhitungan menunjukkan bahwa nilai $\mathrm{p}>0,05$; maka $\mathrm{H}_{3}$ ditolak, yang berarti bahwa ukuran dewan pengawas syariah tidak berpengaruh signifikan terhadap kinerja keuangan perusahaan perbankan di Indonesia dengan ukuran bank sebagai variabel kontrol.

Dewan Pengawas Syariah (DPS) adalah dewan yang bertugas mengawasi kegiatan bank agar sesuai dengan prinsip syariah (PBI No. 11/33/PBI/2009). Menurut Chtourou, dkk (2001) dalam Dewayanto (2010) menyatakan bahwa jumlah dewan yang semakin besar maka mekanisme monitoring manajemen perusahaan akan semakin baik. Dengan demikian, semakin besar jumlah anggota Dewan Pengawas Syariah maka akan meningkatkan pengawasan terhadap pengelolaan bank yang sesuai dengan prinsip syariah, sehingga tidak terjadi penggunaan dana yang tidak berprinsip syariah yang dapat mengurangi kinerja keuangan. Dengan demikian, kinerja keuangan bank akan meningkat.

\section{KESIMPULAN}

Berdasarkan hasil penelitian sebagaimana terlah diinterpretasikan di dalam bab sebelumnya, maka dapat ditarik kesimpulan:

1. Ukuran dewan komisaris berpengaruh positif dan signifikan terhadap kinerja keuangan Bank Syariah Mandiri periode 2013-2016, sehingga $\mathrm{H}_{1}$ diterima.

2. Ukuran dewan direksi tidak berpengaruh signifikan terhadap kinerja keuangan Bank Syariah Mandiri periode 2013-2016, sehingga $\mathrm{H}_{2}$ ditolak.

3. Ukuran dewan pengawas syariah tidak berpengaruh signifikan terhadap kinerja keuangan Bank Syariah Mandiri periode 2013-2016, sehingga $\mathrm{H}_{3}$ ditolak. 


\section{UCAPAN TERIMA KASIH}

Peneliti mengucapkan terima kasih kepada pihak-pihak yang telah mendukung dalam proses penyelesaian penelitian ini antara lain:

1. Kepada Allah SWT dan Orangtua yang telah memberikan doa dan dukungan sehingga bisa sampai saat ini.

2. Bapak dan Ibu Dosen Magister Akuntansi Konsentrasi Syariah yang telah mendukung penulis dalam memperoleh data.

3. Semua Pihak yang telah membantu dalam proses penyelesaian penelitian ini.

\section{DAFTAR PUSTAKA}

Bank Indonesia. 2009. Peraturan Bank Indonesia Nomor 11/33/PBI/2009 tentang Pelaksanaan Good Corporate Governance bagi Bank Umum Syariah dan Unit Usaha Syariah.

Bank Indonesia, Peraturan No. 8/14/PBI/ 2006 tanggal 5 Oktober 2006 tentang Perubahan atas Peraturan Bank Indonesia Nomor 8/4/PBI/2006 mengatur tentang Pelaksanaan GCG bagi Bank Umum.

Bukhori, Iqbal dan Raharja. 2012. Pengaruh Good Corporate Governance dan Ukuran Perusahaan terhadap Kinerja Perusahaan (Studi Empiris pada Perusahaan yang Terdaftar di BEI 2010). Diponegoro Journal of accounting. http://ejournal s1.undip.ac.id/index.php/accounting.

David Tjondro, r. Wilopo. 2011. Pengaruh good corporate governance (gcg) terhadap Profitabilitas dan kinerja saham perusahaan perbankan Yang tercatat di Bursa Efek Indonesia. Pascasarjana STIE Perbanas Surabaya STIE Perbanas Surabaya.

Dewayanto, Totok. 2010. Pengaruh Mekanisme Good Corporate Governance terhadap Kinerja Perbankan Nasional Studi pada Perusahaan Perbankan yang terdaftar di Bursa Efek Indonesia Periode 2006-2008. Fokus Ekonomi. Vol. 5 No.2. p. 104-123.

Forum for Corporate Governance in Indonesia, 2003., Indonesian Company Law. (http://www.fcgi.org.id)

Ghozali, Imam. 2006. Aplikasi Analisis Multivariate dengan Program SPSS. Semarang: Badan Penerbit Universitas Diponegoro.

Sari, Kumala. 2012. Analisis Pengaruh Audit Tenure, Reputasi KAP, Disclosure, Ukuran Perusahaan, dan Likuiditas terhadap Penerimaan Opini Audit Going Concern (Studi Empiris pada Perusahaan manufaktur yang Listing di BEI tahun 2005-2010). Semarang: Fakultas Ekonomika dan Bisnis Universitas Diponegoro.

Susetyo, Budi. 2009. Menuju Teori Stewardship Manajemen. Jurnal Permana.Vol. 1 No.1.

Virda Rakhma Septiputri, Siti Mutmainah 2013. Dampak Corporate Governance Terhadap Profitabilitas Perbankan Syariah Indonesia Tahun 2007- 2011. Diponegoro Journal of Accounting. http://ejournals1.undip.ac.id/ index.php/accounting. 
Wijayanti, Sri dan Siti Mutmainah. 2012. Pengaruh Penerapan Corporate Governance terhadap Kinerja Keuangan pada Perusahaan Perbankan yang Terdaftar di Bursa Efek Indonesia (BEI) Tahun 2009-2011. Diponegoro Journal of Accounting. http://ejournals1. undip.ac.id/index.php/accounting. 